\title{
THE WEIMAR TRIANGLE: FRANCE, GERMANY, POLAND IN THE MIDDLE EAST. UNITED ARAB EMIRATES PERSPECTIVE
}

\section{INTRODUCTION}

The year 2021 is a moment the $30^{\text {th }}$ anniversary of the founding of the Weimar Triangle and the year of the Golden Jubilee of the United Arab Emirates (UAE). The relations between the UAE and the European Union (EU) and its members have been gradually deepening since 2011. It is due to the new dynamics and institutions of the Common Foreign and Security Policy (CFSP) based on the Lisbon Treaty. Moreover, at that time, the Middle East and the EU experienced the effects of the so-called Arab Spring. Another reason is the new US strategy adopted in 2011, which announced a shift of US strategic interest from the Atlantic and the Middle East to Pacific, East Asia (Clinton, 2011). This situation affects the strategies of both European and Middle Eastern countries. The United Arab Emirates has implemented a strategy of foreign and security policy with more focus on the diversification of strategic alliances. Moreover, the United Arab Emirates is changing its income source. The UAE is reducing oil production and focusing on the green economy and renewable energy. In these areas, the European Union has emerged as a valuable strategic partner. However, there is still a belief that it is more effective to conduct policy towards the EU through its leaders than through bureaucratic Brussels. In this regard, the United Kingdom was perceived by the UAE traditionally as one of the most significant partners in bilateral relations and an influential EU member state. However, after the Brexit, this situation changed. In this way, relations with France and Germany gained additional strengths. In 2015, Poland was recognised by the United Arab Emirates as a strategic partner, leader of Central and Eastern Europe. Therefore, Poland had the opportunity to be with France and Germany in a group of the most significant partners, the EU Member States. In these circumstances, the Weimar Triangle established in 1991 by France, Germany and Poland could become a platform for cooperation in the Middle East. The meeting of the Ministers for European Affairs of France, Germany, and Poland in January 2020, and at the beginning of February the official visit of President Emmanuel Macron to Poland with a clear message of the need to revive the Weimar Triangle, after Brexit, provide new impetus to taking new joint initiatives.

The research goal of the article is to show the involvement of the Weimar Triangle countries in relation to the United Arab Emirates. The specific research question that this article deals with on the example of the United Arab Emirates, is whether the 
Weimar Triangle states increasing their role and importance in the external dimension of the European Union? The answer to this question is crucial because it touches upon a fundamental question about the nature of the European Union and its Common Foreign and Security Policy. Thus, this research is part of a broader issue of the European Union's ability to pursue jointly strategic interests and to increase its role and importance in non-European relations. Therefore, future beneficiaries of the answer to be obtained will be researchers of international relations as well as practitioners dealing with the European Union.

\section{LITERATURE REVIEW}

The presented article is the result of many years of the author's personal experience in international processes taking place in the Weimar Triangle countries and the Middle East, as well as the research conducting in this field. Therefore, some of them are worth mentioning. In the article France and West Germany in the Middle East and North Africa-Cooperation or Rivalry (Krzymowski, 2011), the author analyses the activity of two Weimar Triangle states in the Middle East. Moreover, the author published a book entitled Republic of Poland \& United Arab Emirates. 25 Years of Diplomatic Relations (Krzymowski, 2017), which shows the dynamics of relations between Poland and the UAE. Additionally, in the article The Visegrad Group countries: The United Arab Emirates perspective, the researcher analyses the UAE from the Polish foreign policy activity side in the Visegrad Group (Krzymowski, 2021). In a broader sense, the author presents the role of the United Arab Emirates for the European Union in the article The European Union and the United Arab Emirates as civilian and soft powers engaged in Sustainable Development Goals (Krzymowski, 2020).

Despite the broad literature on the Weimar Triangle, it lacks papers about this kind of cooperation related to the Middle East, including the United Arab Emirates. However, it should be noted, that when analysing the Weimar Triangle, Wyligała (2010) emphasizes that different positions regarding the war in Iraq that began in 2003 significantly reduced its activity. In turn, Fiszer and Czasak (2020) indicate that in 2007-2011 the Weimar Triangle was revived and after 2011 weakened again. In the book The Weimar Triangle in Europe. Das Weimarer Dreieck in Europe. Le Triangle de Weimar en Europe, edited by Standke (2009: 248), the author describes the Weimar Triangle as 'the backbone of future Europe'. Yoder (2017) in Dialogues, Trialogues, and Triangles: The Geometry of Germany's Foreign Policy of Trust-Building emphasises that the Weimar Triangle greatly influenced Germany's international relations after the Cold War. However, the researcher also asks about the future role of this collaboration format. Parzymies (2014) in the article Le Triangle de Weimar a-t-il encore une raison d'être dans L'Europe en voie d'unifi cation? analyses the various stages of the Weimar Triangle development. The author underlines the different individual members' interests, which affects the effectiveness of the Weimar Triangle. Norkevičius (2019) in Ph.D. thesis under the title The dimension of regional cooperation in Polish foreign policy underlines the importance of the Weimar Triangle for Poland's role in the international arena. On the other hand, Koszel (2016), in the article The Weimar Triangle: balance 
and perspectives for cooperation, emphasises that despite the existence of many differences of interests between France, Germany, and Poland, the Weimar Triangle should be a platform for the partnership that will effectively strengthen cooperation within the Common Security and Defence Policy of the European Union. However, Heurtaux et al. (2020) in their publication The Third Side of the Weimar Triangle: Franco-Polish Relations in the Trilateral Context, show the strategic differences in the foreign and security policy of individual countries of the Weimar Triangle. Moreover, they raise the question of whether President Macron's visit to Poland at the beginning of 2020 will bring dynamics to this form of cooperation. In this context, Płóciennik (2020) in The Weimar Triangle Returns: Prospects for Cooperation between France, Germany, and Poland emphasises the significance of President Emmanuel Macron's visit to Poland for the revival of the Weimar Triangle and the implementation of new joint economic projects. Massaux (2020) in the publication Quelles perspectives pour le Fonds Européen de Défense au niveau des Etats membres de l'UE: l'exemple du triangle de Weimar draws attention to the persistent differences in the strategies of the Weimar Triangle states and their interests resulting from other schools of thought in international relations and historical experiences. The German vision of foreign and security policy focus on building a network of international ties, including within the European Union and NATO. Through which it pursues its national interests. However, the main goal of France is to build durable strategic independence. On the other hand, Poland, fearing fragmentation of the advancement of European integration, especially in the ground of security and defence, strengthens its strategic alliance with the United States.

\section{RESEARCH METHODOLOGY}

The presented article is based on descriptive and analytical methods. In order to fulfil the intended purpose and find an answer to the research question, the author analysed numerous information, government documents, and activities as well as the literature on the subject. The author's participation as a practitioner in many international relations processes concerning the discussed topic is an added value for the presented analysis. The main area of foreign policy analysis is the intentions, statements, and actions of actors (Gerner, 1995). Foreign Policy Analysis is on the verge of theoretical knowledge about foreign affairs with the practice of international political life. Thus, the International Practice Theory has is adopted in the present research as an appropriate analytical tool to investigate the presented issue. Many researchers, including Barnett and Finnemore (2004) as well as Ringmar (2014) emphasise that the most important subject of international relations analysis is practices. Turner (1994: 43) presents International Practice Theory as a concept that arises through the employment of practitioners' analyses and their transposition into international relations theory.

This research has adopted case studies that are analytical and empirical methods. To this end, was examined the relationship between the UAE and Weimar Triangle states. The implemented case analysis method investigated the chronological sequence of events in the cooperation between the actors, starting from their causes and ending with the observed effect. Then, the presented paper has used qualitative methods to 
clarify the causal and interpretation. It is presented in findings and helped to answer the research question.

\section{UAE-FRANCE}

France's foreign and security policy towards the Arab world has strategic goals and principles with a wide range of cooperation, including economic, cultural, and political (Saint-Prot, 2003: 13). Till May 1998, France was the primary weapon supplier for the UAE and its military cooperation partner. Despite the significance of the United States in the Persian (Arabian) Gulf, especially during the 1990-1991 war. In 1993, the United Arab Emirates bought from France 390 Leclerc tanks and 46 armoured recovery vehicles, instead of the M1A2 tanks proposed by the US. This decision confirmed the role and importance of France for the UAE. In 1995, the United Arab Emirates signed defence cooperation agreements with France and the US. Moreover, in April 1999, the United Arab Emirates signed a contract with the US to purchase 80 F-16 aircraft. Thus, as Dazi-Héni emphasises, the United Arab Emirates has become a competition area between French and American arms suppliers (France, 2007: 54-55). Initially, France-UAE relations were limited to hydrocarbons and security cooperation. During the last ten years, there has been a great dynamic in relations between the two countries. As Cafiero (2018) emphasises, the French military base 'Peace Camp' (Camp de la Paix), located in the United Arab Emirates since 2009, which was the first outside of the so-called French area of responsibility shows the mobilisation of France to compete for influence in the region with both the US and UK. China, Russia, and Turkey are also taking part in this geopolitical competition. In 2012 between the UAE and France initiated a strategic dialogue, which takes place regularly. Since then, joint strategic projects are dynamically completing, in almost all areas. Moreover, in May 2015, in the capital city of Saudi Arabia, the President of France, François Hollande initiated a strategic partnership with the GCC. As emphasised by Aluwaisheg (2015), the purpose of establishing the partnership is political coordination towards regional and global challenges, military cooperation in combating terrorism, economic and energy collaboration as well as cultural cooperation. In this context, it is worth mentioning that 8 million people live in France, which is 12 percent of Arab origin population. Moreover, on 8 November 2017, the Louvre Abu Dhabi museum was inaugurated.

On November 21, 2018, His Highness Sheikh Mohammed Bin Zayed Al Nahyan, Crown Prince of Abu Dhabi, Deputy Supreme Commander of the UAE Armed Forces paid an official visit to France. It happened a year after President Macron visited the UAE. During Crown Prince's visit, the Emirati Mubadala Investment Company signed a contract with the French company Bpifrance to create a joint program in the scope of new innovative technologies, for the amount of EUR 300 million. Both countries' leaders confirmed the deepening of cooperation on energy, environment, climate change, and sustainable development goals. Therefore, a commitment has been made to carry out joint projects in the field of renewable energy, artificial intelligence, and satellite observation for measures to reduce the effects of climate change. Moreover, the leaders confirmed the development of joint initiatives on the green economy, sustainable, 
and smart cities. The UAE and France have recognised the Sustainable Development Goals as a strategic priority in both individual and joint operations. In this sense, it was decided to support the UNIT LIFE initiative. In addition, both sides committed to acting together for international peace and security. Both partners agreed to conduct joint operations to combat terrorism, counteracting extremism in the MENA region, as well as improve humanitarian aid (Joint Statement, 2018).

French Secretary of State for the Ecological and Inclusive Transition, Brune Poirson on June 30, 2019, participated in the 'Abu Dhabi Climate Meeting for the UN Climate Action Summit'. For France, which held the G7 Presidency at the time, taking actions to mitigate the effects of climate change was one of its main priorities. France strived to ensure that the goals of the Paris Agreement signed in 2015 are implementing. Therefore, the minister met with the UAE Minister for Climate Change and Environment Thani Al Zeyoudi. They discussed the participation of French entities in the solar park of Mohammed bin Rashid Al Maktoum as well as in Expo 2020 Dubai, in which innovative projects related to renewable energy and sustainable development are priorities. In addition, ministers emphasised the importance of joining the Space Climate Observatory (SCO) for cooperation between the UAE Space Agency the French National Space Research Centre (CNES). SCO is a project initiated by France in 2019 to exchange satellite and field data, and conduct research to monitor and model climate change as well as its impact on a global and local scale. It is also working on establishing indicators and tools to support decision-making in a coordinated and interdisciplinary way, including with social and economic sciences, to increase bond capacity to mitigate the effects of climate change (Hatem, Hassan, 2019). During the meeting, partners decided to strengthen strategic cooperation in renewable energies, waste management, the protection of biodiversity, and the development of green finance. Therefore, the talks also covered the actions of financial institutions such as the Abu Dhabi Investment Authority, which is a significant part of the coalition of state funds initiated by President Emmanuel Macron in Paris in December 2017 during the One Planet Summit.

On 27 and 28 October 2019, the Minister of Europe and Foreign Affairs of France, Jean-Yves Le Drian visited the United Arab Emirates. During a meeting with H. H. Sheikh Abdullah Bin Zayed Al Nahyan, the Minister of Foreign Affairs and International Cooperation of the UAE, both partners expressed the readiness for further actions to mitigate the effects of climate change. They adopted a letter of intent regarding the Emirati - French partnership on the 17 Sustainable Development Goals of the UN 2030 Agenda (France Diplomacy, 2019). Moreover, in January 2020, the Minister of Foreign Affairs and International Cooperation of the UAE met in Paris with the Minister for Europe and Foreign Affairs of France Jean-Yves Le Drian. The interlocutors discussed situations in the Middle East, especially issues related to Iran and Libya. Moreover, they analysed a strategic partnership between the two countries. Partners stressed that cooperation should be dynamized, in particular in the area of science and culture. Therefore, ministers confirmed joint actions on creating the Centre for Artificial Intelligence at Sorbonne University in Abu Dhabi (MOFAIC, 2020). Just two days later, the Secretary-General of the French Ministry of Europe and Foreign Affairs, François Delattre, came to Abu Dhabi. In the first words, he emphasised 
France's readiness to deepen the strategic partnership. As a part of strategic dialogue, based on a far-reaching vision of cooperation, it was decided to look for new joint innovative strategic projects. During his stay in the UAE, the Secretary-General of the French Ministry of Europe and Foreign Affairs visited the French Navy Base in Abu Dhabi, where Admiral Didier Maleterre reported the opening of the headquarters of the European Maritime Awareness Mission in the Strait of Hormuz a few days earlier (EMASOH). The idea of this mission was initiated by France, Germany, and the UK in November 2019. Currently, it is being conducted by France, with the support of Belgium, Denmark, Germany, Greece, Italy, the Netherlands, and Portugal. The project demonstrates solid close military cooperation between France and the UAE (Embassy of France in Abu Dhabi, 2020). Moreover, the President of the French Constitutional Council in January 2020, Laurent Fabius visited the UAE. During this visit to Abu Dhabi, the French delegation met, among others, with the Minister of Foreign Affairs and International Cooperation, H.H. Sheikh Abdullah bin Zayed Al Nahyan, the Minister of Climate Change and Environment Thani Ahmed Al Zeyoudi. Additionally, they participated in the World Summit on the Future of Energy and the Week of Sustainable Development in Abu Dhabi. Laurent Fabius, who presided over COP21 in December 2015, called for urgent implementation of the Paris Agreement during this global conference. Bilateral meetings have confirmed that the priority of cooperation is actions to mitigate effects of the global warming, environmental protection, and sustainable development. Additionally, as part of the World Summit on the Future of Energy, the winner of the Zayed Sustainability Prize in the energy category was the French NGO 'Electriciens sans frontières' (Embassy of France in Abu Dhabi, 2020). On June 3,2020, the annual strategic dialogue session between the UAE and France took place, during which both parties adopted a new action plan for 2020-2030. Participants discussed cooperation in economy, trade, investment, oil and gas, nuclear and renewable energy, education, culture, space, security, and health. Both sides decided to support each other in overcoming the COVID-19 pandemic. Partners adopted the area of artificial intelligence as a pillar of strategic partnership. Moreover, both sides expressed interest in cooperating in resolving crises in the Middle East, joint economic projects in the MENA area, as well as actions contributing to global peace, security, and development (MOFAIC, 2020).

\section{UAE-GERMANY}

Political and economic relations between Germany and the United Arab Emirates are very strong. In 2004, both countries signed a strategic partnership agreement. As Ackermann, Director General for the Middle East, and Africa at the German Ministry of Foreign Affairs emphasises, the United Arab Emirates is the only Arab country with which relations have been raised to strategic. For Germany, trade with the UAE accounts for almost 22 percent of trade with the Arab world, being the largest trading partner in the Middle East. More than 900 German companies operate in the United Arab Emirates, with a particular interest in the field of renewable energy sources (Al Oraibi, 2019). Over the past ten years, trade has increased by 57.8 percent, from USD 
8.4 billion in 2010 to USD 13.25 billion in 2018. In addition, Germany cooperates with the United Arab Emirates in third countries, such as implementing projects in Afghanistan. The pursuit of Germany's interests in the Middle East, unlike United Kingdom, France, Spain, and Italy, is not burdened by the colonial past. Its foreign policy towards this region was based primarily on supporting a regional balance of power, combating cross-border terrorist organizations, and participating in post-conflict reconstruction operations. In 2014, during the $50^{\text {th }}$ security conference in Munich, President Joachim Gauck emphasised that it is time for Germany to play an effective role in the Middle East. Moreover, he underlined that his country has the political, military, and economic capabilities to do so. Moreover, Gauck called for an end to limiting the pursuit of German interests by using military instruments, assuming a greater role in international affairs, including being active in resolving conflicts in the Middle East. On December 4, 2015, the Lower House of the German Parliament (Bundestag), authorised the German army to engage in a counter-terrorism mission, as well as approved the federal government's plan to join the military campaign against ISIS in Syria and Iraq. Two weeks later, on December 19, 2015, a terrorist attack took place in Berlin, rushing into the crowd at the market by an ISIS member Anis Amri. He killed 12 people and injuring dozens of other people. This situation justified further German military action in the Middle East (FARAS, 2017). The transformation of Germany's strategy towards the Middle East, from a 'quiet player' to an 'active player' took place in mid-2016. A change in policy has taken place in the face of threats of terrorism in Germany, illegal migration originating from the Middle East, as well as the UK's decision on Brexit. It should also be noted, that at this time, was a serious crisis in relations between Germany and Turkey, which has huge regional ambitions. This tension between both countries resulting from the granting of asylum by Germany to Turkish military officers. They were suspected of participating in the failed coup in Turkey that took place in July 2016. In addition, in ranks of Kurdish People's Protection Units (YPG), which are an essential part of the so-called Syrian Democratic Forces (SDF) in Syria were many fighters of German nationality (FARAS, 2017).

Since 2017, energy and climate policy has been the foundation of cooperation under the energy partnership. Both countries have adopted the role of leading in renewable energy sources and carrying out an ambitious energy transformation towards efficient and low-carbon energy supplies. Therefore, both sides decided jointly to engage in promoting a global low-carbon and climate-friendly economy. Moreover, they want to utilise Expo 2020 Dubai to promote strategic cooperation in infrastructure and smart cities. The main goal for Germany and the United Arab Emirates is to be a place of innovative solutions. To achieve this goal, both governments decided to support the private companies and $\mathrm{R} \& \mathrm{D}$ institutions for joint investment projects. In this context, representatives of the United Arab Emirates informed German partners that the UAE had just adopted a new law on Foreign Direct Investment (FDI). Its goal is to increase FDI and to attract advanced technologies (Embassy of the UAE in Berlin, 2019).

The UAE and Germany regularly discuss for more than 10 years to develop innovative economic projects under the Joint Economic Commission. Such a forum also took place in Berlin in March 2019, chaired by the UAE Minister of Economy Sultan Bin Saeed Al Mansouri, and the Federal Minister of Economy and Energy Peter Altmaier. 
During the Commission, both parties focused primarily on the search for new methods, and initiatives that would further accelerate cooperation between companies in areas related to the implementation of Sustainable Development Goals (SDGs). They demonstrated special interest in the field of energy, climate policy, and the green economy, infrastructure, metrology, health, education and training, technical cooperation, World Expo 2020, and Smart Cities. It is worth noting that companies from Germany, including Siemens and Wintershall, have been awarded strategic contracts in the media, oil, and gas sector. In Dubai, the largest industrial group in Germany, Siemens will open its global logistics headquarters for airports, cargo logistics, and seaports. Siemens invested in this project USD 7 billion and is expected to start operations in 2021. Moreover, this company is involved in projects for an ecological future, primarily in cooperation with the Dubai Electricity and Water Authority to develop a solar-powered hydrogen project at the Mohammed bin Rashid solar park in the desert region of Seih Al Dahl. Siemens is also the Expo 2020 Dubai's official premier partner. This company in November 2018 in Abu Dhabi opened a centre of digital technology and artificial intelligence to concentrate on water, oil, and gas cooperation. Siemens wants to spend USD 500 million on this centre. In contrast, the German company Wintershall, which is part of the world's largest chemical corporation BASF Group, decided to invest in the energy sector in Abu Dhabi. This company in 2018 received a ten percent share in the Ghasha ultra-acid and 40-year license. This is the first time a German company got a mining contract in the United Arab Emirates. In this way, Wintershall will be able to produce over 1.5 billion cubic feet of gas and over 120,000 barrels of condensate per day. Germany is also very involved in the Expo 2020 Dubai project. The 4500 square meters German pavilion, built for EUR 50 million, will attract worldwide attention to German achievements in the field of new technologies. Additionally, the German 'vertical campus' is located as part of the exhibition space dedicated to sustainable development. Moreover, visitors will be able to see various solutions for sustainable design and artificial intelligence (The National, 2019). In September 2019, during a meeting in Abu Dhabi with the Minister of Foreign Affairs and International Cooperation, H. H. Sheikh Abdullah Bin Zayed Al Nahyan, Minister of State at the German Federal Foreign Office, Niels Annen emphasised that Germany wants to implement energy and transport projects with the UAE, cities, education, and healthcare (Salman, AbdulKader, 2019).

\section{UAE-POLAND}

France and Germany set up official ties with the United Arab Emirates in the seventies. Directly after the formation of this state. Poland established diplomatic relations with the United Arab Emirates on September 4, 1989. This year was unique for Poland, Europe, and the world. Thanks to the Polish Solidarity movement, communism fell, and the Berlin Wall collapsed. As a consequence, Poland has contributed to building a new European and world order. In this atmosphere, Warsaw has started building its latest role and international position as well as pursuing its interests in the world with a new partner, including the United Arab Emirates. The history of relations between 
Poland and the UAE so far is characterised by periods of completely different dynamics. From 1989 to 1995 it was a period of hard work, signing the first agreements and identifying effective tools for pursuing interests. During this period, Prime Minister Waldemar Pawlak's first visit to the UAE took place. However, from 1995, until 2004, relations between the two countries did not record any noticeable dynamics. It could be due to the fact that the Polish authorities focused their efforts on integration with NATO and the European Union. After the war started in Iraq in March 2003 and the $1^{\text {st }}$ of May 2004 accession to the EU, in November 2004, the Polish government announced strategies towards the Middle East. In this document, Poland's government identified the United Arab Emirates as one of the priority countries in this region. In that year, President Aleksander Kwasniewski came with an official or working visit to 10 Middle East countries, including the United Arab Emirates. The next president, Lech Kaczyński, also recognised the Middle East as a crucial region for Polish foreign and security policy (Bieleń, 2011: 392-394). However, despite some activity in supporting economic relations, from 2005 to 2010, there was a continuation (from 1995) of a stagnancy.

The year 2011 brought fundamental changes that led in 2015 to strategic relations between Poland and the United Arab Emirates. At the turn of February and March 2011, the Minister of Agriculture and Rural Development came to the UAE. As a result of this visit, a few months later, the United Arab Emirates lifted the banned import of Polish beef to the UAE. Poland got this decision as one of the first European Union member states. Moreover, in May of the same year, the Minister of Foreign Affairs of the UAE, H.H. Sheikh Abdullah Bin Zayed Al Nahyan paid his first visit to Poland. At the invitation of Crown Prince Abu Dhabi, in January 2012, the Deputy Prime Minister and Minister of Economy visited the UAE. Just two months later, Prime Minister Donald Tusk paid an official visit to the United Arab Emirates. It was the first visit of the head of government since 1994. Consequently, in February 2013, the first Joint Commission for Economic Cooperation took place in Poland with both countries' ministers of economy, and a large UAE delegation. In this visit also participated H. H. Sheikh Ahmed Bin Saeed Al Maktoum. In addition to numerous meetings, there was also a meeting with Prime Minister Donald Tusk. As a result of the dynamic development of relations between both countries, in December 2013, President Bronisław Komorowski paid an official visit to the United Arab Emirates. In March 2014, the UAE lifted the requirement to apply for an entry visa for Polish citizens coming to this country. In June the same year, the Minister of Foreign Affairs of the United Arab Emirates H.H. Sheikh Abdullah Bin Zayed Al Nahyan paid an official visit to Poland for the second time. In April 2015, the Polish Deputy Prime Minister, Minister of Economy came to the UAE to participate in the Joint Commission for Economic Cooperation. He also took part in business forums, in Abu Dhabi and Dubai (Krzymowski, 2017: 141-144). In June 2015, there was a historic visit to Poland paid by H.H. Sheikh Mohammed Bin Rashid Al Maktoum, Vice President, Prime Minister of the United Arab Emirates, and Ruler of Dubai. It was the first visit to Poland at such a high level of the United Arab Emirates representative. The UAE delegation noted that Poland achieved the position of a strategic partner for the United Arab Emirates. In addition, the following agreements were signed during the visit: Agreement on cooperation in the field of 
tourism; MoU on cooperation in higher education and research; MoU on cooperation in the field of innovation and small and medium-sized enterprises; MoU in the field of agriculture, food safety, research cooperation and marketing in agriculture and food. Additionally, during the visit H.H. met with President-Elect Andrzej Duda, for whom he was the first foreign guest. H.H. Sheikh Mohammed Bin Rashid Al Maktoum emphasised that the fifth year of developing very close relationships and expressed hope for further development (Krzymowski, 2017: 141-144).

However, in the period 2016-2017, there was no official bilateral visit at the minister level or above. In April 2018, the Deputy Prime Minister, Minister of Culture and National Heritage came to the UAE, participating in the International Book Fair in Abu Dhabi. Thanks to the decision taken in 2015 by the UAE authorities, Poland was the Honorary Guest of this event. In February 2019, the Minister of Agriculture and Development came to Dubai to participate in the Gulf Food fair. In November 2019, the UAE Minister of Infrastructure and Development visited Warsaw, where a maritime transport agreement was signed, negotiated in April 2015. In October 2019, H. H. Sheikh Sultan Bin Muhammad Al Qasimi, the Ruler of Sharjah, came to Krakow with a private visit. He visited the Jagiellonian University at its invitation. The visit resulted from direct cooperation between the Jagiellonian University and the University of Sharjah, of which H.H. is the president.

\section{FINDINGS}

As Saint-Prot (2017: 80) emphasises the reasons for the United Arab Emirates to seek and consolidate diversified alliances, among others, are the consequences of US military intervention in Iraq launched in March 2003, as well as American paranoia regarding Muslims and nationals Arab, expressed in the Patriot Act. This bill was in force for nearly 15 years, from the end of October 2001 to June 1, 2015. Moreover, in January 2006, George W. Bush in the State of the Union address, said that the United States must reduce its dependence on oil from the Middle East. Another situation unfavourable to relations with the US was their disagreement that the United Arab Emirates corporation Dubai Ports World took over the British group P\&O, and thus gained control of six American seaports.

The European Union's strategic goal is striving to achieve coherence in the area of its external action. Therefore, cooperation within the Weimar Triangle could become one of the elements stimulating the development of integration processes for the entire EU seeking to develop a common strategy including a Common Foreign and Security Policy, and the European Neighbourhood Policy. The main European Union objectives are adequate for the policies of the Weimar Triangle countries. France, Germany, and Poland's strategic goals are the European Union as a dynamic entity and a key player in the international arena, using its potential to pursue common interests in the world (Krzymowski, 2011: 46). All three states of the Weimar Triangle conduct foreign and security policy in the region, with different perceptions. The presence of France in the Mediterranean region and the Middle East has a long history. Geographical proximity of this region, strategic, political, military, and economic interests, as well as close 
personal contacts between elites, have contributed to the 'Politique Arabe de la France' (Vernochet, 2009). It is one of the pillars of French foreign policy and security strategy. France is expanding its strong presence in the Middle East and North Africa (MENA) as an area of strategic national interests, including in the Gulf Cooperation Council (GCC) countries. However, to implement this strategy, France needs a politically and economically strong Europe as an instrument for achieving the global role and position of France in the international system. It will ensure its significant influence in the world, going beyond its national potential. In January 2003, just before the American intervention in Iraq, President J. Chirac emphasised that France's interests were identical to Europe. However, in terms of P $5+1$ (Germany) and the Joint Comprehensive Plan of Action (JCPOA), France has its own economic interests. Since the adoption of JCPOA, the first Western energy company that signed an agreement with Iran was the French energy giant company, Total. This French corporation has wanted to use access to some of the South Pars gas fields. For Paris, the JCPOA issue is part of a broader strategy towards the Persian (Arab) Gulf, and the Middle East. France strives to be a recognised mediator by all countries in the region, between Saudi Arabia and Iran. Paris wants to provide a platform for cooperation between these countries and Israel. Since June 2017, France was the most engaged of all European countries in mediation between Qatar and other GCC members (Cafiero, 2018). In terms of the fight against terrorism, France recognises the United Arab Emirates as a trusted partner. However, whether can France effectively create a new geopolitical order for the Persian (Arab) Gulf? By trying to accomplish this strategy, Paris will face the challenge, perceiving by regional actors France as not neutral. The French president is determined to confirm his country as a military power on a global scale. In this sense, securing influence in the Arab region is key to this strategy.

French political, economic, and military interests in the Middle East, in the last few years, have acquired a global dimension. That is why its presence in the region has grown. However, whether can France alone succeed in competing with other powers for influence in the Middle East. One should agree with Karasik (2019) that French significance in the Persian (Arabian) Gulf is associated with the French arms industry interests and its importance for the economy. In this way, it affects France's foreign and security policy. Since 2015, France has been at the top three arms exporters to the region, especially to Saudi Arabia and the United Arab Emirates. At the International Exhibition and Defence Conference (IDEX) in Abu Dhabi in February 2019, Paris signed with the UAE further long-term contracts. Karasik (2019) asks the question, could France be a guarantor of the region's security? However, this concept would face the resistance of powers competing France in the region, as well as within the EU. Therefore, this strategy could only be effective within the European Union. In this sense, the Weimar Triangle could also play its role.

German economic interests primarily focus not on the supply of energy from this region but on increasing exports and economic presence there, which will lead to greater interest in political stability and security in the Persian (Arab) Gulf region (Hubel, Berger, Heise, 2005). Chancellor Angela Merkel's strategy of Germany's presence in the Middle East is based on 7 pillars. First of all, Germany supports strategic partners in the region. Therefore, in May 2017, the German Chancellor paid visits to 
Saudi Arabia, the United Arab Emirates, and Egypt. The second element of the strategy is political instruments for conflict resolution. Especially in the period 2012-2013, Bashar al-Assad repeatedly stressed that Germany should be a mediator of the conflict. For the implementation of the German strategy, NGOs have a significant role. One example is the Berghof Foundation, which was involved in the arrangement of informal negotiations between the conflict parties in Yemen. In these activities participated a special UN envoy in Yemen, Ismail Ould Cheikh Ahmed. Stabilisation based on a balance between crucial regional powers is another pillar of German policy in the region. The fourth element of the strategy is combating terrorist organisations. The fifth pillar is to stop Iran from supporting armed groups in Syria and Iraq. It was pointed by German Vice-Chancellor and Foreign Minister Sigmar Gabriel with his French counterpart Jean-Yves Le Drian on May 22, 2017, during a joint press conference. Another pillar of the strategy is non-acceptance for the construction of refugee camps in conflict zones that generate waves of migrants to Europe. The seventh pillar of the policy is an activity in the reconstruction of post-conflict countries in the Middle East. In the process of strengthening the political, economic, and military foundations in these countries, Germany has the opportunity to pursue national interests (FARAS, 2017). So, Sandschneider (2010: 22) points out, the goal of Germany's foreign and security policy is to deepen strategic cooperation with countries such as the UAE to create bridges between the world of Islam and the West. It is necessary, especially in the multipolar world order. It also implies the role of Europe and the Persian (Arabian) Gulf. Therefore, partners from this region, as Sandschneider emphasises, will carefully watch not only the economic but also the political activities of Germany in the Middle East.

Poland is a country playing an increasingly important role and achieving a growing position in international relations, including in the Middle East. Poland has extensive experience of involvement in this area, including taking many years of engagement in the UN missions and having close political and economic contacts with the region's states for years. One of the priorities of the Polish presidency of the EU (second half of 2011) was energy security, which is still a key potential area of cooperation with this region. Both Paris and Berlin supported the Polish presidency's goal. Moreover, during the Polish presidency of the EU regarding security, the Middle East required special attention and effective joint involvement of the Weimar Triangle countries. It was significant due to the so-called Arab Spring. Minister Jadwiga Emilewicz rightly points out that Poland has a great opportunity in the UAE to propose innovative solutions in areas such as renewable energy, transport, education, telemedicine, and water management (Zalewski, 2019). Moreover, Deputy Minister Marcin Ociepa underlines that the United Arab Emirates is a strategically important partner in the Gulf and Middle East region (PAP, 2018). Therefore, it is necessary to return to the dynamics of visits from the period 2011-15, where Poland reached the level of other Weimar Triangle countries. Also, cooperation within the Economic Commission, whose last meeting took place in 2015 in the UAE, should be revived. Both Germany and France regularly cooperate under this formula, which brings results. After 2015, taking Poland as an example, almost all the Three Seas Initiative's countries established Economic Commissions with the United Arab Emirates. It has resulted in a dynamic of trade growth 
and participation in joint strategic projects. Poland again should be recognised as the 3SI's leader. It will contribute to a significant increase of Poland's role in the Weimar Triangle, also vis-à-vis the GCC countries, including the United Arab Emirates.

Figure 1. Top-level official bilateral visits in the UAE

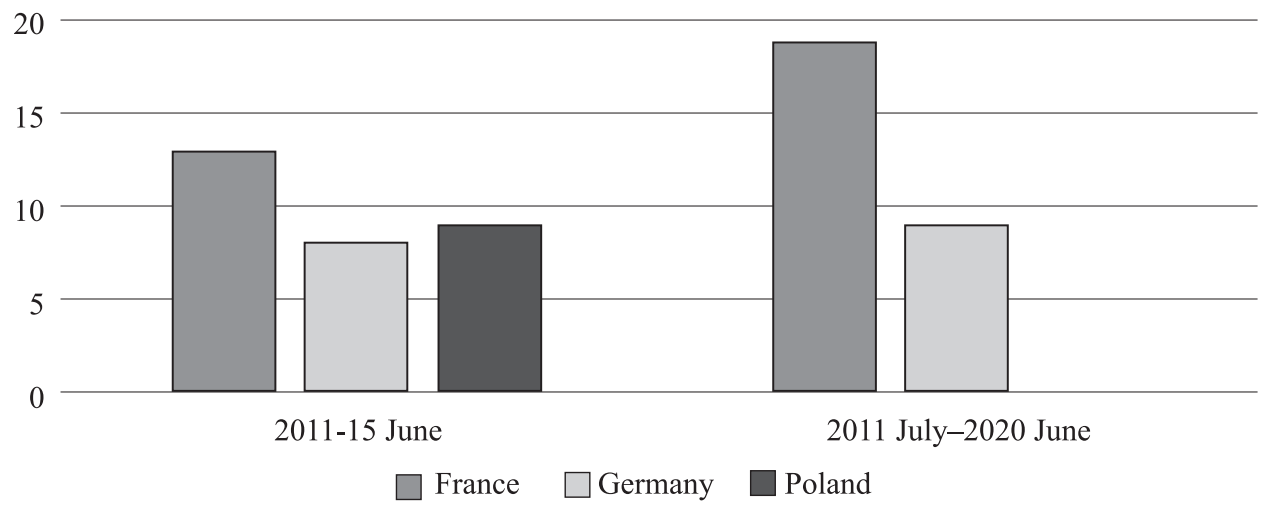

Source: Own study based on data from government institutions.

The Weimar Triangle countries should give a new character to this form of cooperation, enriching it with new instruments for joint involvement in the region. For the Weimar Triangle countries, the Middle East is significant not only because of the growing economic and trade potential. The situation in this region is also affecting Europe, as well as global security architecture. For this reason, the Weimar Triangle should build a coherent and comprehensive EU foreign and security policy towards the Middle East, as well as GCC. For France, Germany is the primary partner in the implementation of the new combat system. It consists of a new generation combat aircraft, an unmanned aerial vehicle (UAV), the Future Combat Air System (FCAS), and new tanks - Main Ground Combat System (Gotkowska, 2020: 4). In this context, during the discussions on February 3, 2020, in Warsaw, President Macron proposed the joint realisation of a new generation tank project that could initiate broader cooperation in the defence industry. In addition, France and Poland had prosperous talks concerning cooperation about new technologies, including energy. During the visit, both partners signed the Polish French Strategic Partnership Cooperation Program and the Declaration of intentions to strengthen joint work on cybersecurity. These areas of cooperation could include contractors from the UAE.

The Middle East is determined primarily by the rivalry between Iran and Saudi Arabia over shaping geopolitics. At the same time, Europe is losing its position in the region in favor of Asian countries, especially China and India. A new geostrategic axis is emerging with a political and economic dimension. Therefore, in global rivalry, the conclusion of a Free Trade Agreement between the European Union and the GCC as well as greater European Union involvement in the region, including coherent, coordinated actions of the Weimar Triangle (Krzymowski, 2011: 50) have strategic importance. France, Germany, and Poland have common interests in strengthening the EU's competitiveness. Ministers responsible for economic affairs of the Weimar 
Triangle's countries and Italy, on February 4, 2020, forwarded to the Executive Vice President of the European Commission for A Europe Fit for the Digital Age and Competition, Margrethe Vestager joint letter in which they call for involvement in creating large European companies. It is the answer to the increasingly aggressive competition from the US and China (Braun, Larger, Van Dorpe, 2020). Therefore, it seems desirable to revive the Weimar Triangle and undertake joint projects with their presence in the Middle East, including the United Arab Emirates. For the Weimar Triangle, energy issues are of strategic importance and constitute an area of cooperation. It is also worth noting that Hélène Pelosse from France was the first head responsible for International Renewable Energy Agency (IRENA) based in Abu Dhabi, United Arab Emirates, which officially started its operations in 2011. In April 2011, Poland was the only Central and Eastern European country, one from six European countries, together with France and Germany, elected to the Council of the International Renewable Energy Agency. In October 2011, German Minister of Foreign Affairs, Westerwelle inaugurated the crucial institution of IRENA, Innovation, and Technology Centre based in Bonn (German Federal Foreign Office, 2011). Weimar Triangle countries want to diversify their energy sources. During the France president's visit in February 2020 in Poland, both sides decided to extend the Polish French working group on energy to include climate issues. This group should work in the field of nuclear and renewable energy. Moreover, both partners agreed to undertake joint initiatives on environmental issues and sustainable development, especially under the Eco-City program: water, waste management, smart cities, green technologies (Prezydent, 2020: 5). Therefore, the Weimar Triangle countries should be one of the major platforms to coordinate joint and EU projects in the Middle East. Involvement in the region has not only economic or trading significance but a strategic one. It should be a test and question of whether the European Union is a community of interests with a joint strategic vision or only an organisation in which its members, using lofty slogans on community, only want to pursue national interests. In the long run, the answer to this question will determine the EU's persistence. The rivalry between China and India, as well as Russia and Turkey activities in the Middle East is increasing. Therefore, an effectively coordinated Weimar Triangle could be perceived as a desirable formula for the GCC countries. World Expo in Dubai, which will take place from October 10, 2021, to March 31, 2022, is an opportunity to present joint projects.

The presented findings of scientific research on the cooperation of the Weimar Triangle countries with the United Arab Emirates are the first in this area. Therefore, the results are a contribution to new knowledge in international relations. Moreover, they can provide an organised source of information, guidance, and inspiration for practitioners.

If the European Union wants to be an influential actor in a globalised system of international relations, it need not only reforms, and institutional changes, but first and foremost, new sources of political and strategic initiatives. The Weimar Triangle may become a forum that will give political impetus to the entire enlarged EU in the con- 
text of global competition. Cooperation within the Weimar Triangle can provide the European Neighbourhood Policy the proper meaning and significance, understanding its Eastern and Southern dimensions. Moreover, it can maintain the entire European Union from sterile internal competition. The strength of the European Neighbourhood Policy lies in the 'global approach', in geographical terms as well as in areas of cooperation (Krzymowski, 2011: 52). Thus, the presidents of Poland and France in February 2020 emphasised the need to maintain two equivalent dimensions of the European Neighbourhood Policy (Eastern and Southern) as a priority of the European Union's foreign policy (Prezydent, 2020: 11). Poland and France will coordinate their positions in the European Union on the main challenges related to international relations, also the Middle (Middle East Peace Process, Syria, Iran, etc.). The presidents of Poland and France agreed that areas of cooperation could be extended to Germany as part of the Weimar Triangle (Prezydent, 2020: 12). During the meeting in Warsaw in June 2020, the foreign ministers of Poland and Germany agreed that the European Union should have an important role in foreign policy, including cooperation with the Middle East (PAP, 2020). One should agree with Płóciennik that the significance of the Weimar Triangle is strengthened by challenges facing the EU, including those related to developments in the Middle East (Płóciennik, 2020: 2). As Kleiber emphasises (2018), the future of the Weimar Triangle appears to be extremely important politically and economically, also having great importance for the stability of development of the entire European Union. If the European Union wants to play an important role in the system of international relations, it must be coherent and active. This role can certainly be fulfilled by the dynamized Weimar Triangle. There is no cooperation with the EU without considering Central and Eastern Europe. Poland, having the largest population, territory and the highest GDP is the natural leader of this region in the European Union. In view of common global challenges, it would be desirable to establish a high-level political dialogue on key issues in the region, including readiness to discuss differences in their perception. France is currently the best candidate for this dialogue, but Germany with one of the strongest world economies, and Poland as the leader of the Three Seas Initiative should also be involved.

\section{REFERENCES}

Alfaham T. (2019), UAE, EEAS hold first Senior Officials' Meeting to launch the Cooperation Arrangement, "WAM", https://www.wam.ae/en/details/1395302776990 (07.07.2020).

Al Oraibi M. (2019), Germany has only praise for strategic UAE relations, "The National”, https:// www.thenational.ae/world/germany-has-only-praise-for-strategic-uae-relations-1.847996 (08.07.2020).

Awad M. (2013), UAE boosts diplomatic presence in Europe, “The National”, Dubai, https://www. thenational.ae/uae/government/uae-boosts-diplomatic-presence-in-europe-1.292926 July 2019).

Barnett M., Finnemore M. (2004), Rules for the world: International organizations in global politics, Cornell University Press, Ithaca, NY.

Bieleń S. (ed.) (2011), Poland's Foreign Policy in the 21st Century, Warsaw. 
Braun E., Larger T., Van Dorpe S. (2020), EU big four press Vestager to clear path for champions, "Politico", https://www.politico.eu/article/eu-big-four-france-germany-italy-poland-pressexecutive-vice-president-margrethe-vestager-to-clear-path-for-champions/ (07.02.2021).

Cafiero G. (2018), French ambitions in the Gulf, "TRT World”, https://www.trtworld.com/opinion/ french-ambitions-in-the-gulf-14588 (05.07.2020).

Clinton H. (2011), America's Pacific Century: The future of politics will be decided in Asia, not Afghanistan or Iraq, and the United States will be right at the Centre of action, "Foreign Policy", November.

Council of the European Union (2010), 20 th EU-GCC Joint Council and Ministerial Meeting, Joint Communique, Presse 197, Luxembourg, 14 June.

Council of the EU (2015), EU signs visa waiver agreement with the United Arab Emirates. Press release, http://data.consilium.europa.eu/doc/document/ST-7103-2015-INIT/en/pdf (07.07.2020).

EEAS (2016), Federica Mogherini, HR/VP meets with Dr. Amal Al Qubaisi, UAE Federal National Council Speaker in Brussels, Press releases: 160818_2, Brussels, https://eeas.europa.eu/ headquarters/headquarters-homepage_is/8363/Federica\%20Mogherini, $\% 20 \mathrm{HR} / \mathrm{VP} \% 20$ meets\%20with\%20Dr.\%20Amal\%20Al\%20Qubaisi,\%20UAE\%20Federal\%20National\%20Council\%20Speaker\%20in\%20Brussels (05.07.2020).

EEAS (2018), EU and UAE sign a Cooperation Arrangement, Press releases: 180131_15, Bruxelles, https://eeas.europa.eu/headquarters/headQuarters-homepage_it/39170/EU\%20and\%20 UAE\%20sign\%20a\%20Cooperation\%20Arrangement (17.07.2020).

Embassy of France in Abu Dhabi (2020), France and the UAE are preparing the next decade of their strategic partnership: French Envoy, https:/ae.ambafrance.org/France-and-the-UAE-arepreparing-the-next-decade-of-their-strategic-partnership (07.03.2021).

Embassy of France in Abu Dhabi (2020), Visit of Laurent Fabius to the United Arab Emirates, https:// ae.ambafrance.org/Visit-of-Laurent-Fabius-to-the-United-Arab-Emirates (07.01.2021).

Embassy of the UAE in Berlin (2019), $11^{\text {th }}$ Session of the German - UAE Joint Commission, Berlin, https://sp.mofaic.gov.ae/EN/DiplomaticMissions/Embassies/Berlin/AboutMission/ Pages/11th-Session-of-the-German--UAE-Joint-Commission.aspx (07.07.2020).

Esraa I. (2018), UAE's total trade with the European Union reached EUR 52 billion, "WAM", http:// wam.ae/en/details/1395302680408 (07.07.2020).

Esraa I., Rasha A. (2019), UAE a global model for promoting peace through humanitarian role in Yemen, says EU President, "WAM", http://wam.ae/en/details/1395302732327 (14.07.2020).

European Commission (2015), The Participation Of The European Union In Various Organisations For Cooperation To Prevent And Counter Terrorism, Joint Decision Of The European Commission And The High Representative Of The Union For Foreign Affairs And Security Policy, Join(2015) 32 Final, Brussels, 27.8.2015, https://eur-lex.europa.eu/legal-content/EN/ TXT/HTML/?uri=CELEX:52015JC0032\&from=EN (07.07.2020).

EU (2011), EU High Representative Catherine Ashton visits the Gulf, MEMO/11/250, Brussels, 17 April, https://ec.europa.eu/commission/presscorner/detail/en/MEMO_11_250 (07.07.2019).

FARAS (2017), Pillars of Germany's Foreign Policy for Middle Eastern Conflicts, "Future for Advanced Research and Studies", Abu Dhabi, https://futureuae.com/en-US/Mainpage/ Item/2899/pillars-of-germanys-foreign-policy-for-middle-eastern-conflicts\# (17.07.2019).

Fiszer J., Czasak M. (2020), Trójkąt Weimarski. Geneza i działalność na rzecz integracji Europy w latach 1991-2016, Warszawa.

France Diplomacy (2019), United Arab Emirates - Visit by Jean-Yves Le Drian, Minister for Europe and Foreign Affairs, "Ministry for Europe and Foreign Affairs", Paris, https://www.diploma- 
tie.gouv.fr/en/country-files/united-arab-emirates/events/article/united-arab-emirates-visitby-jean-yves-le-drian-minister-for-europe-and-244959 (04.07.2020).

France and the Arabian Gulf (2007), "The Emirates Center for Strategic Studies and Research".

German Federal Foreign Office (2011), Federal Minister Westerwelle to deliver a speech at the official opening of the IRENA Innovation and Technology Centre in Bonn, Press release, https:// www.auswaertiges-amt.de/en/newsroom/news/111006-bm-irena/247336 (07.07. 2019).

Gerner D. J. (1995), The Evolution of the Study of Foreign Policy in Foreign Policy Analysis: Continuity and Change in its Second Generation, Prentice Hall, Englewood Cliffs-New Jersey.

Gotkowska J. (2020), Europejska autonomia strategiczna czy europejski filar w NATO? Niemcy wobec inicjatyw Macrona, „Komentarze OSW”, No. 320, Ośrodek Studiów Wschodnich, Warszawa, https://www.osw.waw.pl/sites/default/files/komentarze_320.pdf (07.01.2021).

Hatem M., Hassan B. (2019), UAE Space Agency joins Space Climate Observator, "WAM", http:// wam.ae/en/details/1395302768724 (07.03.2020).

Heurtaux J., Zerka P., Tulmets E. (2020), The Third Side of the Weimar Triangle: Franco-Polish Relations in the Trilateral Context, "Genshagener Papier", No. 24, http:/www.stiftung-genshagen.de/uploads/media/Genshagener_Papier_No._01.pdf (07.01.2021).

Hubel H., Berger L., Heise M. (2005), German Foreign Policy in the Gulf, The Emirates Center for Strategic Studies and Research, "The Emirates Occasional Papers”, No. 58.

Joint Statement (2020), On the Visit to France of H.H. Sheikh Mohammed Bin Zayed Al Nahyan to France, Embassy of France in Abu Dhabi, https://ae.ambafrance.org/Joint-Statement-on-thevisit-to-France-of-H-H-Sheikh-Mohammed-Bin-Zayed-Al (05.12.2020).

Karasik T., Ober T. (2019), France's Expanding Military Influence in the Arabian Gulf, "Inside Arabia", https:/insidearabia.com/france-expanding-military-influence-arabian-gulf/ (07.02.2020).

Koszel B. (2016), Trójkąt Weimarski: bilans i perspektywy wspótpracy, „Krakowskie Studia Międzynarodowe", Vol. XIII, No. 1: 65-82, ISSN 1733-2680 e-ISSN 2451-0610.

Kleiber M. (2018), Trójkąt Weimarski. Naturalna konsekwencja ugruntowanej wspótpracy, https://wszystkoconajwazniejsze.pl/prof-michal-kleiber-trojkat-weimarski-naturalnakonsekwencja-ugruntowanej-wspolpracy/ (07.07.2019).

Krzymowski A. (2020), The European Union and the United Arab Emirates as civilian and soft powers engaged in Sustainable Development Goals, "Journal of International Studies", Vol. 13, No. 3: 41-58, DOI:10.14254/2071-8330.2020/13-3/3.

Krzymowski A. (2021), The Visegrad Group countries: the United Arab Emirates perspective, "Politics in Central Europe", Vol. 17, No. 1: 107-126, DOI: 10.2478/pce-2021-0005.

Krzymowski A. (2011), Francja i RFN na Bliskim Wschodzie i w Afryce Pótnocnej-Wspótpraca czy Rywalizacja, „Zeszyty Naukowe AON”, Vol. 85, No. 4.

Krzymowski A. (2017), Republic of Poland \& United Arab Emirates. 25 Years of Diplomatic Relations, Dubai.

Malek C. (2014), EU sets up international centre in Abu Dhabi, "The National", Dubai, https:// www.thenational.ae/uae/government/eu-sets-up-international-centre-in-abu-dhabi-1.255060 (08.07.2019).

Massaux A. (2020), Quelles perspectives pour le Fonds Européen de Défense au niveau des Etats membres de l'UE: l'exemple du triangle de Weimar, "Paix et sécurité européenne et internationale", Université de Nice Sophia Antipolis, https://hal.archives-ouvertes.fr/hal-03154826/ document (07.07.2021). 
MOFAIC (2020), H.H. Sheikh Abdullah bin Zayed meets EU High Representative, "News", https://www.mofaic.gov.ae/en/mediahub/news/2020/1/23/23-01-2020-uae-european-union (17.07.2020).

MOFAIC (2020), H.H. Sheikh Abdullah bin Zayed meets with French FM, "News", https://www. mofaic.gov.ae/en/mediahub/news/2020/1/24/24-01-2020-uae-france (12.08.2020).

MOFAIC (2020), The 12 $2^{\text {th }}$ Session of the UAE-France Strategic Dialogue Endorses Ambitious 10Year Bilateral Roadmap, https://www.mofaic.gov.ae/en/mediahub/news/2020/6/3/03-062020-uae-france (27.08.2020).

Mouriadou G. (2016), EU-GCC Clean Energy Technology Network, "Working Groups Consultation Workshop", Dubai, http://www.eugcc-cleanergy.net/wg-workshop2016\%2CDubai (07.07.2019).

Norkevičius M. (2019), The dimension of regional cooperation in Polish foreign policy, Vytautas Magnus University, "Doctoral Thesis".

PAP (2018), PolskieRadio24.pl, „Gospodarka”, https://www.polskieradio24.pl/42/1699/ Artykul/2212478, Wymiana-handlowa-miedzy-Polska-a-Zjednoczonymi-EmiratamiArabskimi-ma-wzrosnac-w-2019-r-do-1-mld-USD (07.07.2019).

PAP (2020), MSZ: Wizyta ministra Heiko Maasa w Warszawie (komunikat), http://centrumprasowe.pap.pl/cp/pl/news/info/161019,25,msz-wizyta-ministra-heiko-maasa-w-warszawie(komunikat) (17.01.2021).

Parzymies S. (2014), Le Triangle de Weimar a-t-il encore une raison d'être dans L'Europe en voie d'unifi cation?, "Stosunki Międzynarodowe", Vol. 50, No. 2: 183-198.

Płóciennik S. (2020), Powrót Weimaru - perspektywy dla wspótpracy Francji, Niemiec i Polski, „Biuletyn”, No. 19 (1449), PISM, Warszawa.

Prezydent (2020), Polsko-francuskie partnerstwo strategiczne. Program wspótpracy, https://www. prezydent.pl/aktualnosci/wydarzenia/art,1664,wizyta-prezydenta-francji.html (07.03.2021).

Ringmar E. (2014), The search for dialogue as a hindrance to understanding: Practices as interparadigmatic research program, "International Theory", Vol. 6, No. 1.

Saint-Prot C. (2003), French Policy Towards the Arab World, The Emirates Center for Strategic Studies and Research, "Emirates Lecture Series", No. 42.

Salman N., AbdulKader B. (2019), Over 560,000 German tourists visited UAE in 2018: German Minister, "WAM". https://wam.ae/en/details/1395302789936 (07.07.2020).

Sandschneider E. (2010), German Foreign Policy towards the Gulf Region, The Emirates Center for Strategic Studies and Research, "Emirates Lecture Series", No. 86.

Sheena A. (2019), UAE ranked world's top aid donor in 2017: OECD, "Dubai Gazette", Dubai, https://dubaigazette.com/uae-ranked-worlds-top-aid-donor-in-2017-oecd/ (07.07.2020).

Standke K-H. (red.) (2009), Trójkąt Weimarski w Europie. Das Weimarer Dreieck in Europa. Le Triangle de Weimar en Europe, Toruń.

Stur B. (2017), Jyrki Katainen: "There is untapped trade potential between GCC and Europe", "New Europe", https://www.neweurope.eu/article/jyrki-katainen-untapped-trade-potentialgcc-europe/ (07.07.2019).

Vernochet J. (2009), La politique arabe de la Franceen en question, "Geopolintel”, 31 juillet, http:// www.geopolintel.fr/article112.html (07.07.2019).

The National (2019), German-UAE economic and trade ties go a long way, Dubai, https://www.thenational.ae/business/economy/german-uae-economic-and-trade-ties-go-a-long-way-1.873170 (17.07.2020).

Turner S. (1994), The social theory of practices: Tradition, tacit knowledge, and presuppositions, University of Chicago Press, Chicago. 
WAM (2016), EU praises UAE's drive for renewable energy, https://www.emirates247.com/news/ emirates/eu-praises-uae-s-drive-for-renewable-energy-2016-04-29-1.628755 (07.07.2019).

WAM (2018), UAE-EU trade hits \$65bn, Dubai, http://emirates-business.ae/uae-eu-trade-hits-65bn/ (07.07.2019).

Wyligała H. (2010), Trójkąt Weimarski. Wspótpraca Polski, Francji i Niemiec w latach 1991-2004, Toruń.

Yoder J. A. (2017), Dialogues, Trialogues and Triangles: The Geometry of Germany's Foreign Policy of Trust-Building, "German Politics", Vol. 26, No. 2: 195-218, DOI: 10.1080/09644008.2016.1250888.

Zalewski A. (2019), Kreatywność inspirowana natura - Polska na EXPO 2020 w Dubaju!, „Biotechnologia.pl”, https://biotechnologia.pl/biotechnologia/kreatywnosc-inspirowana-naturapolska-na-expo-2020-w-dubaju,18909 (07.07.2020).

\begin{abstract}
The article's scientific goal is to investigate the Weimar Triangle countries' relations with the United Arab Emirates. Therefore, the author asks the research question. Are the Weimar Triangle states' role and significance increasing in the external dimension of the European Union? Based on the example of the United Arab Emirates, the research adopted a hypothesis. It is the statement that after Brexit, the Weimar Triangle countries have a chance to improve their importance in the EU external activities. Apart from case studies, to revise the hypothesis, the author performed a meticulous comparative analysis. Moreover, the research implemented International Practice Theory as an appropriate tool to investigate the presented issue. This empirical research and its findings resulted from over ten years of the author's direct observation, analysis, and participation in many initiatives, both in the European Union and in the United Arab Emirates.

The Middle East for the Weimar Triangle countries is more significant than just from a trade potential perspective. The situation in this region is also affecting Europe, as well as global security architecture. For this reason, one should develop a coherent and comprehensive EU foreign and security policy towards the region, and the Weimar Triangle formula should be one of its pillars.
\end{abstract}

Keywords: Weimar Triangle, Middle East, France, Germany, Poland, United Arab Emirates, European Union

\title{
TRÓJKĄT WEIMARSKI: FRANCJA, NIEMCY, POLSKA NA BLISKIM WSCHODZIE. PERSPEKTYWA ZJEDNOCZONYCH EMIRATÓW ARABSKICH
}

\section{STRESZCZENIE}

Celem naukowym artykułu jest zbadanie stosunków państw Trójkąta Weimarskiego ze Zjednoczonymi Emiratami Arabskimi. Dlatego też, autor stawia pytanie badawcze. Czy rola i znaczenie państw Trójkąta Weimarskiego wzrasta w zewnętrznym wymiarze Unii Europejskiej? Na przykładzie Zjednoczonych Emiratów Arabskich w badaniu przyjęto hipotezę. Jest to stwierdzenie, że po Brexicie, państwa Trójkąta Weimarskiego mają szansę zwiększyć swoje znaczenie w działaniach zewnętrznych UE. Oprócz studiów przypadków, w celu zrewidowania 
hipotezy, autor przeprowadził skrupulatną analizę porównawczą. Ponadto, jako odpowiednie narzędzie do zbadania przedstawionego zagadnienia, przyjęto Teorię Praktyki Międzynarodowej (International Practice Theory). Niniejsze badania empiryczne i jego wyniki są rezultatem ponad dziesięciu lat autora bezpośredniej obserwacji, analiz i uczestniczenia w wielu inicjatywach, zarówno Unii Europejskiej, jak i Zjednoczonych Emiratów Arabskich.

Bliski Wschód dla krajów Trójkąta Weimarskiego jest ważniejszy niż tylko z perspektywy potencjału handlowego. Sytuacja w tym regionie ma również wpływ na Europę i globalną architekturę bezpieczeństwa. Dlatego też, należy rozwijać spójną i kompleksową politykę zagraniczną i bezpieczeństwa UE, wobec tego regionu, a jednym z jej filarów powinna być formuła Trójkąta Weimarskiego.

Słowa kluczowe: Trójkąt Weimarski, Bliski Wschód, Francja, Niemcy, Polska, Zjednoczone Emiraty Arabskie, Unia Europsejska 